UDC 338.45:658.5

V.Shvets ${ }^{1}$, Dr. Sc. (Econ.), Prof., orcid.org/0000-0002-9016-1101, L. Palekhova ${ }^{1}$, Cand. Sc. (Econ.), Assoc. Prof., orcid.org/0000-0003-0217-5755,

D. Palekhov ${ }^{2}$, Cand. Sc. (Law.), PhD (Env. Sc.), orcid.org/0000-0001-6041-668X, S.Simon², Dr.-Ing. Habil., Prof., orcid.org/0000-0001-5970-7201
DOI: $10.29202 /$ nvngu/2018/23

1 - National Mining University, Dnipro, Ukraine, e-mail: palehovall@gmail.com; vasil-shvetc@ukr.net

2 - Brandenburg University of Technology Cottbus - Senftenberg, Cottbus, Germany, e-mail: dmitry.palekhov@b-tu.de; Sylvio.Simon@b-tu.de

\title{
ENERGY EFFICIENCY CRITERIA AS A FOCUS FOR MARKET-DRIVEN STRATEGIES OF LARGE COMPANIES IN TRANSITION ECONOMIES
}

Purpose. The purpose of the presented research is to reveal the critical importance of energy efficiency indicators for large industrial companies from countries with economies in transition for increasing their competitiveness in local and global markets.

Methodology. This article presents a historical overview of common principles and approaches to energy efficiency in the context of transition to sustainable development in countries with different economic policies, including countries with economies in transition. The research was based on the analysis of the international documents and reports, statistical data and national practices relating to energy efficiency and energy saving.

Findings. The study highlights the extent of the problem of energy efficiency in countries with economies in transition, and identifies the causes for a lack of sufficient progress in achieving the energy sustainability of their large companies as a key driver for competitiveness and successful integration into global value chains. At the same time, the authors analysed the factors which contributed to the remarkable success of some countries with a socialist past in re-orientation of the governmental policy towards energy security and achieving sustainable economic growth. The system approach allowed to identify a number of the key factors related to energy efficiency and their impact on the achievement of competitive advantage. And, finally, the authors proposed a set of contextual criteria for the selection of potential market strategies aimed to position large companies as a part of complex value chains with a global dimension.

Originality. The conducted analysis revealed that large companies in countries with economies in transitional have to take into account two groups of energy efficiency criteria for their integration into sustainable markets: 1) criteria related to the company's ability to improve the situation in its country or region; 2) criteria related to requirements and standards that are maintained or important for a particular value chain, into which the company is entering or intends to enter.

Practical value. The significance of the new approach is that the company can change or expand the 'push strategy' for positioning its business on external market, which is currently a common practice of Ukrainian enterprises. The suggested system of criteria can become a basis for the development of the 'pull strategy', which would focus on sustainable development goals of all three groups of stakeholders: companies, region or country, and business partners within the value chain.

Keywords: energy efficiency, global value chains, market strategies, sustainable development, transition economy

Introduction. Over the course of recent years, the problem of energy efficiency of manufacturing companies has become an increasingly important subject of discussions on sustainably in the industrial sector, which drew much attention across the globe. EU member states as a whole managed to achieve impressive results in this field by shifting out and reorientation of energyintensive industries, and through technical and technological modernisation, especially in the manufacturing sector. However, even with substantial improvements in the energy efficiency of all leading corporations of Europe and the world, the globally required transition to sustainability cannot be achieved without integrating appropriate energy goals into development programmes of countries with economies in transition. The majority of countries with economies in transition are not yet

(C) Shvets V., Palekhova L., Palekhov D., Simon S., 2018 ready to make a stable progress towards achievement of the energy sustainability goals. With a few exceptions, efforts and subsequent results have been quite uneven across these countries, and can be, in general, characterised as insufficient in their quality and scope. Indeed, some countries of Central and Eastern Europe (CEE), such as Czech Republic, Slovakia and Poland, have a relatively higher level of implementation of measures in the field of energy goals, especially after joining the EU and becoming a subject to EU policies. But in most post-Soviet countries, including Ukraine, energy sustainability perspective still remain a long way off [1].

Analysis of the recent research. It is worthwhile to note that scientific debates on energy management in the industrial sector have recently increased. In context of this research, of particular interest are the last monographic publications in this field, including those on the fundamental principles and systematic processes of 
maintaining and improving energy efficiency by Craig B. Smith \& Kelly E. Parmenter [2], energy efficiency management for the process industries by Alan P. Rossiter \& Beth P. Jones [3], interdisciplinary approach to the various barriers with energy efficiency by Patrik Thollander \& Jenny Palm [4]. Ukrainian scientists investigate the role of energy management and government control of energy-savings in industry (e.g. O. Kambur \& Y. Kostenok [5]), the need for energy efficiency and problems of implementation of energy management system (e.g. K.O.Bratkovska [6]), approaches for the improvement of energy efficiency (e.g. R. Sevastyanov [7]), and others. Nonetheless, the capacity of energy efficiency strategies for the formation of competitive advantages in the industrial markets remain poorly understood.

Unsolved aspects of the problem. Under the socialist distribution system, energy resources of all types were exchanged freely across administrative borders; Moscow provided funds and management necessary to maintain energy infrastructure. The collapse of the socialist system created a new reality - new independent states and the former socialist countries faced a wide range of impediments to achieving their future progress, particularly in the field of energy security and environmental sustainability.

Firstly, not all new states were able to secure an adequate access to fossil energy sources. Most of the economies in transition (with an exception of resource-rich Kazakhstan and the Russian Federation) now have a significant dependency on energy imports. For example, Ukraine does not have a sufficient supply of its own natural energy resources; its energy sector faces great challenges, ranging from a high dependence on expensive fossil fuel imports, such as oil and natural gas, to inefficient infrastructure and markets [8].

Until recently, almost all of the imported gas was from the Russian Federation. Over the past two years, however, the situation has gradually improved. Ukraine has adopted the long-term energy security strategy [9], and was able to significantly reduce external energy vulnerability by increasing the national production and diversification of energy supplies. Moreover, the country is increasing its export potential of electricity. In 2016, its electricity exports rose further, and had amounted to \$152.063 million, including \$119.317 million to Hungary, $\$ 32.392$ million to Poland, $\$ 0.347$ million to Moldova [10].

Secondly, in countries with economies in transition, the implementation of sustainable development goals requires deliberate public policies on the energy efficiency, including policies affecting energy efficiency of all types - in industry and agriculture, construction and housing sector, transport and other spheres. Today, each of these areas is considered as a necessary part of the overall strategic programme in the context of accelerating the country's transition to sustainable development.

Ukrainian experience clearly demonstrates that a more diversified national policy on energy imports contributes to improving the country's energy security; its positive effects are strengthened by reduction of total energy consumption, including in the production sector [11]. The persisting trends in energy intensity of production and consumption patterns continue to deplete nonrenewable resources, especially in Ukraine and the Russian Federation, where many industrial facilities still retain energy- and resource-intensive technologies and processes. These countries have one of the highest energy intensity per unit of production in the world, at a level almost three times higher than that, for example, of Germany or Italy (Table 1).

Indeed, energy intensity of the industrial sector, an indicator calculated as the amount of energy to value added at purchasing power parity of 2005 (koe/\$05p), in 2014 was 0.26 in Ukraine and 0.23 in Russia, while in Germany it totalled only to 0.07 [12]. The high energy intensity and non-competitive prices of Ukrainian industrial production are mainly attributable to the use of wasteful outdated technologies, the slow pace of technical re-equipment and modernisation of existing facilities, and a weak interest in the international energy management standards. This problem was considered in more detail in previous studies [13, 14].

Thirdly, countries with economies in transition generally have very limited policy options for diversifying energy sources. In its ambition for economic growth, Ukraine is already facing challenges of reliable power supply for the needs of the industrial sector and ensuring energy services for the population, which is largely due to high dependence on fossil fuels and rising energy prices. At the same time, the experience of Germany and Italy, for example, shows that a reasonable policy aimed at diversification of energy sources and electricity generation is a necessary component of sustainable development, and sustainable energy objectives should become a part of the macro-economic framework in each country.

In particular, the German energy policy, which faced a major change after the government adopted a new energy concept in September 2010, is targeting sustainability and focusing on a continuous increase in power gen-

Table 1

Energy intensity of countries with transitional economies in comparison with Germany and Italy [12]

\begin{tabular}{|l|c|c|}
\hline \multicolumn{1}{|c|}{ Country } & $\begin{array}{c}\text { Energy intensity } \\
(\text { koe } / \$ 05 \mathrm{p})\end{array}$ & $\begin{array}{c}\mathrm{CO}_{2} \text { intensity } \\
\left(\mathrm{kCO}_{2} / \$ 05 \mathrm{p}\right)\end{array}$ \\
\hline Germany & 0.07 & 0.24 \\
\hline Italy & 0.07 & 0.19 \\
\hline Slovakia & 0.08 & 0.24 \\
\hline Poland & 0.08 & 0.38 \\
\hline Romania & 0.08 & 0.28 \\
\hline Czech Republic & 0.09 & 0.37 \\
\hline Serbia & 0.10 & 0.50 \\
\hline Kazakhstan & 0.12 & 0.69 \\
\hline Russian & 0.16 & 0.72 \\
Federation & 0.19 & 0.73 \\
\hline Ukraine & & \\
\hline
\end{tabular}


eration from renewable sources, a reduction of primary energy usage and $\mathrm{CO}_{2}$ emissions [15]. A strong emphasis is placed on the state support for the development of renewable energy - the Renewable Energy Sources Act (Erneuerbare-Energien-Gesetz, EEG) guarantees a fixed price, independent of demand and supply for renewable power. Subsidies for renewable energy and investments to integrate the renewable energy into the overall energy system also play a major role in the removal of barriers to the growth of the sector. Germany is one of the leading EU states in the field of renewable energy - as of 2016, the share of renewable energy in its total electrical energy consumption was $31.7 \%$ [16].

Italy has one of the most efficient thermoelectric generation systems in Europe. Its energy sources mix is dominated by natural gas and renewable energy: gas $48 \%$, renewable $28 \%$, coal $15 \%$, oil $3 \%$, other $7 \%$. Italy's current policy, in particular, is focused on the following action fields: an extension of the incentives scheme for $P V$ installations, retrofitting of buildings and energy storage systems [12]. The country adopted programmes to support the production of energy from solar $P V$ and solar thermal plants in buildings and businesses (Conto Energia) and encourage measures to increase energy efficiency and the production of thermal energy from renewable sources (Conto Termico 2.0). In addition, there is a 20 -year plan for funding non-solar renewable energy, such as wind, geothermal energy, biomass and thermodynamics. This set of measures aims to lower the burden of incentives on energy bills, increase the share of renewables in thermal technologies, and improve their efficiency.

At the same time, in Ukraine the share of renewable energy reaches only $6.5 \%$. The recommendations of the World Energy Council note that Ukraine has significant potential in this area. In particular, it should fully utilise alternative options, such as biogas and municipal waste for heating and power generation. Also renewable energy can be actively used to reduce gas consumption in the district heating to ensure heat supply and lower energy bills [12].

Fourthly, for a number of countries there is a problem with principles of fairness, equity, and distributive justice in the field of energy services. In this context, energy equity is understood as the accessibility and affordability of modern energy services within a country or region for all potential consumers, including for business purposes and population. Although various official reports analyse a set of energy equity indicators, it should be emphasised that these challenges are the consequence of country-specific conditions, priorities and capabilities. For example, Ukraine faces all main problems typical for the majority of post-Soviet countries, including monopolisation of energy services and weak transparency of energy producers. These issues were analysed in the dedicated chapters of the monograph "Management for Sustainable Development in Transitional Economies", which was prepared by the joint efforts of scientists from different countries on the initiative of the Brandenburg University of Technology Cottbus-Senftenberg, Germany and National Mining University, Ukraine [17].
Objectives of the article. The purpose of the presented research is to reveal the critical importance of energy efficiency indicators for large industrial companies from countries with economies in transition for increasing their competitiveness in local and global markets.

Methods. Applied methods include the following: historical overview of principles and approaches, analysis of international documents, standards and national practices in the field of energy efficiency, as well as methods of analysis, synthesis, comparison and expert evaluation.

Presentation of the main research. The probably greatest challenge to all countries with economies in transition is the environmental sustainability of energy production and consumption. The Brundtland Report recognises sustainable development as distinct from environmental protection, and suggests that economic development should be ecologically viable and that environmental protection should not preclude economic development. However, in practice, this principle is very difficult to achieve, because this involves searching for various alternatives, compromises and other efforts, both from the side of businesses and from the side of governments, as well as from producers, consumers and other players in the field of production, services and consumption.

This is of particular relevance to countries with a socialist and Soviet past, where environmental objectives have been majorly ignored, and the economy has developed on the basis of continuously increased overexploitation of natural resources. At the same time, some of these countries have shown a remarkable success in reorientation of the public policy towards environmentally sustainable economic growth.

For example, the former GDR and Czechoslovakia produced more than $70 \%$ of energy from brown coal (i. e. lignite) - the dirtiest type of fossil fuels, and countries took almost no measures to protect the atmosphere from industrial pollution [18]. The modern national energy policy of the Czech Republic includes plans for a gradual transition from mostly extracted lignite deposits to natural gas and renewable energy sources for electricity and heat production, with domestic coal remaining for now a stable segment of the country's energy mix (decreasing from $45 \%$ today to less than $20 \%$ in the coming decades). Today, the trilemma of the Czech Republic is well balanced, with a particularly high score in energy equity, where it ranks $5^{\text {th }}$ worldwide [12].

Taking into account the experience of countries leading in energy sustainability, Ukraine also adopted a policy of reducing the share of fossil fuels in its energy mix. It is expected that already in 2017 the coal consumption by thermal power stations and combined heat and power stations will decrease by $16.2 \%$, compared to the previous year. Furthermore, the Minister of Energy and Coal Industry declared that Ukraine intends to abandon the use coal of the anthracite group by the end of 2019.

Analysis in the previous section demonstrated that energy problems vary from country to country both in magnitude and in scale. However, countries with econ- 
omies in transition, especially former socialist countries and former Soviet republics, have inherited approximately the same problems, in particular: a lack of business experience, weak development of market regulatory mechanisms, unsustainable practices regarding the use of natural and fossil resources, wasteful attitude to energy due to low energy prices, large-scale negative consequences of anthropogenic activities. It should be emphasised that understanding of the common problems related to energy sustainability in countries with economies in transition is important not only for improvement of public policies dealing with energy vulnerability, but also for the analysis of conditions, opportunities and threats to the development of business in these countries. This is particularly important in the modern period, when international contacts of companies go beyond import or export operations and should be reconsidered in the context of globalised and multifaceted production, trade and service relationships.

As a result of globalisation processes, companies enter into a system of sequential interactions between participants of production and supply processes, i.e. global value chains or GVCs, where each participant performs a certain function in the creation of a final product. Modern GVCs are rapidly developing, expanding vastly to monumental proportions and growing into complex forms of network structures. When considering the task of integrating or extending its participation in the global market, a company - especially from a country with weak positions in the global economic cooperation - should take a due account of the economic, energy and environmental characteristics, which are fundamental for the strength and stability of this system.

Since today's GVCs have become the main form of economic relations in the world, it is they that came to the forefront of international attention to sustainable development, especially with regards to energy sustainability that can be expressed as energy trilemma. Numerous international conferences and forums, including UN conferences and summits of the G20 leaders, discuss measures for strengthening the sustainability in GVCs [19]. A number of specific actions are aimed at creating and expanding preferences for countries with less developed economies that are facing serious problems of energy efficiency, implying that this will give an impetus to the sustainability of their economies.

In this respect, major companies that have the greatest significance and influence in the domestic economy are increasingly stressed by two groups of factors, which have to be considered for maintaining stability of their business. Regarding the energy sustainability, the first group is related to the company's influence on improving the situation in its country, as well as the general situation in the region. The second group is specifically related to requirements and standards, which are maintained or important for a particular GVC (or its main links and participants). Both groups of these criteria are closely intertwined and have the long term and continuous effects.
It should be noted that requirements for energy sustainability of Ukrainian companies will inevitably be increased. Under the Ukraine-European Union Association Agreement, Ukraine has to introduce to its national legislation over 350 legislative acts, 180 of which had to be introduced by 2017. A number of acts regulating energy sector have already been implemented, including Directive 2009/28/EC on the promotion of the use of energy from renewable sources. The new legislation introduced provisions for demonopolisation of consumer access to power grids, stimulation of the production of thermal energy from renewable energy sources, and others. These reforms correspond to the progressive trends towards sustainable development in GVCs. Of course, the emphases and conditions may vary depending on the specific characteristics of the business and internal and external environment, and therefore, a special study has to be carried out to clarify the contextual criteria.

Many experts and politicians express concerns that Ukrainian companies cannot compete on open markets. In fact, the task is somewhat different - to find a GVC, which would be consonant with the strategic goals of Ukraine and which could benefit from the expertise and resources of the company. Subsequently it will be necessary to make necessary efforts to develop a unique offer that will meet the objectives and standards of this value chain [20].

Table 2 demonstrates a set of contextual criteria that have the greatest significance for market strategies of large companies in Ukraine. These criteria were specified through a survey of top managers of two metallurgical enterprises. In particular, this may be one of the resource strategies, which is based on the quality of a resource or competence and can improve energy efficiency in the chain.

While developing their business strategies, large companies in countries with transitional economies have to take into account two groups of factors (Figure):

1. Criteria that are related to the company's ability to improve the situation in its country, as well as generally in the region.

2. Criteria that are related to requirements and standards, which are maintained or important for a particular value chain, into which the company is entering or intends to enter.

Both groups of contextual criteria are closely intertwined and have the long term and continuous effects for business success of a company. Based on the selected criteria, the company can develop a strategy that will be the most useful for all stakeholders - for its business for its region and country, and also correspond to the best interests of its partners.

The key principle of the new approach would be that the company can change or expand the 'push strategy' for positioning its business on external market, which is currently a common practice of Ukrainian enterprises. Following such strategy the company is ready to cooperate with any external partner that can bring economic benefits.

The suggested system of criteria can become a basis for the development of the 'pull strategy', which would 
Contextual criteria for market strategies of Ukrainian companies [20]

\begin{tabular}{|c|c|c|}
\hline Main problems of Ukraine & $\begin{array}{l}\text { Influence of the company on the } \\
\text { country and region }\end{array}$ & Influence of GVC on the company \\
\hline Insufficient own energy resources & $\begin{array}{l}\text { Stability or reduction of total energy } \\
\text { consumption }\end{array}$ & $\begin{array}{l}\text { Programmes for the reduction of energy } \\
\text { footprint }\end{array}$ \\
\hline $\begin{array}{l}\text { Inadequate balance of the energy } \\
\text { sources }\end{array}$ & $\begin{array}{l}\text { Reduction of primary energy and } \\
\text { resources use }\end{array}$ & $\begin{array}{l}\text { Support for international industry standards } \\
\text { (e.g. IRMA) }\end{array}$ \\
\hline $\begin{array}{l}\text { High energy intensity of Ukrainian } \\
\text { products }\end{array}$ & $\begin{array}{l}\text { Reducing the energy intensity of } \\
\text { production }\end{array}$ & $\begin{array}{l}\text { Reducing energy intensity along the global } \\
\text { production chain }\end{array}$ \\
\hline $\begin{array}{l}\text { Slow pace of technical re-equipment } \\
\text { and modernisation of existing facilities }\end{array}$ & $\begin{array}{l}\text { Technical and technological } \\
\text { modernisation }\end{array}$ & $\begin{array}{l}\text { Established criteria for production and quality } \\
\text { of products }\end{array}$ \\
\hline $\begin{array}{l}\text { Weak state support for the } \\
\text { development of alternative and } \\
\text { renewable energy }\end{array}$ & $\begin{array}{l}\text { Participation in governmental } \\
\text { programmes for the development of } \\
\text { alternative and renewable energy }\end{array}$ & $\begin{array}{l}\text { Programmes and projects on alternative and } \\
\text { renewable energy } \\
\rightarrow\end{array}$ \\
\hline Monopolisation of energy services & $\begin{array}{l}\text { Support for alternative energy service } \\
\text { companies }\end{array}$ & $\begin{array}{l}\text { Programmes for partnerships in the area of } \\
\text { energy technology }\end{array}$ \\
\hline $\begin{array}{l}\text { Weak transparency of energy } \\
\text { companies }\end{array}$ & $\begin{array}{l}\text { Implementation of transparency and } \\
\text { social responsibility standards }\end{array}$ & $\begin{array}{l}\text { Support for international standards on social } \\
\text { responsibility and transparency (e.g. EITI) } \\
\text { Support of projects on counteracting tax evasion } \\
\text { (e.g. "Base Erosion and Profit Shifting") } \\
\rightarrow\end{array}$ \\
\hline $\begin{array}{l}\text { Low environmental sustainability of } \\
\text { energy production and consumption }\end{array}$ & $\begin{array}{l}\text { Introduction of international } \\
\text { standards for environmental and } \\
\text { energy management }\end{array}$ & $\begin{array}{l}\text { Programmes and projects on reduction of } \\
\text { ecological footprint Support for international } \\
\text { environmental standards }\end{array}$ \\
\hline $\begin{array}{l}\text { Weak transparency of energy } \\
\text { companies }\end{array}$ & $\begin{array}{l}\text { Implementation of transparency and } \\
\text { social responsibility standards }\end{array}$ & $\begin{array}{l}\text { Support for international standards on social } \\
\text { responsibility and transparency (e.g. EITI) } \\
\text { Support of projects on counteracting tax evasion } \\
\text { (e.g. "Base Erosion and Profit Shifting") } \\
\rightarrow\end{array}$ \\
\hline
\end{tabular}

focus on sustainable development goals of all three groups of stakeholders:

a) the company: market positioning and reputation as a driver for energy sustainability in its industry and region;

b) region or country: stimulation of transformation processes towards energy sustainability;

c) value chain: obtaining a business partner that shares the vision and goals for sustainable development, extend-

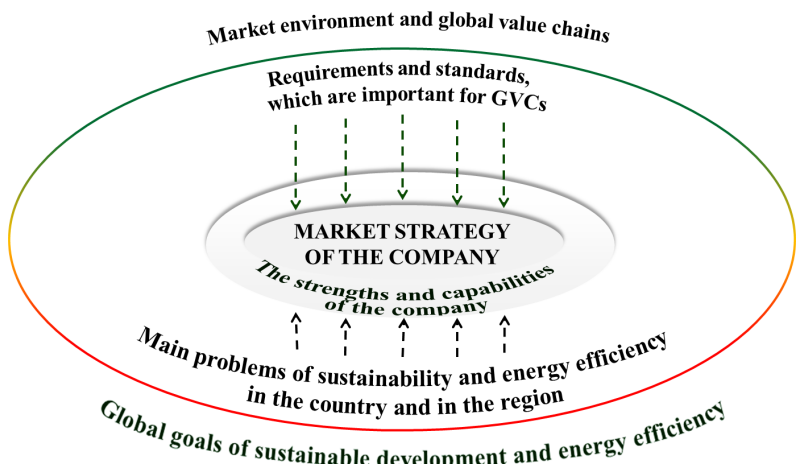

Fig. Energy efficiency criteria in the market strategies of a large companies ing own influence on the market and region, ensuring benefits for all on the basis of sustainability standards.

Conclusions and recommendations for further research. Analysis of the energy efficiency problems, which are determined by the realities of countries with economies in transition, allowed to identify the following action fields important for the development of business strategies of large companies.

Firstly, most of the economies in transition, such as Ukraine, have significant dependency on energy imports. This dependence is especially evident in case of large enterprises that are relying on traditional energy sources and have a high energy intensity of production.

Secondly, under the influence of global processes, in countries with economies in transition there is a gradual transformation of public policies towards energy efficiency.

Thirdly, Ukrainian experience clearly demonstrates that a more diversified national policy on energy imports contributes to improving the country's energy security. At the same time, positive effects may be diluted by a relative increase in energy consumption, especially in the production sector. 
Fourthly, countries with economies in transition generally have very limited policy options for diversifying energy sources, and they, therefore, face challenges of unreliable energy supply, which is largely due to the high dependence on fossil fuels and rising energy prices.

Fifthly, for a number of countries there is a problem with principles of fairness, equity, and distributive justice in the field of energy services. In Ukraine, such issues include monopolisation of energy services and a weak transparency of energy producers.

Finally, the greatest challenge to all countries with economies in transition is the environmental sustainability of energy production and consumption.

Companies that have the greatest significance and influence in the domestic economy should consider these factors not only as a problem, but also as the direction of their possible positive influence. In this regard, they need to be compared with values and standards that constitute the basis for the functioning of the particular value chain, and which are followed by its major players.

The new approach will allow companies to change the traditional strategy for promotion of their business on external markets, which mainly relies on 'pushing' their interests. Considering the whole range of interests - business, region/country and partners within value chain - will produce a 'pull' effect with a multilateral solution of energy efficiency problems and building the capacity for long-term development of the business.

\section{References.}

1. Energy Charter Secretariat, 2013. In-Depth Review of the Energy Efficiency Policy of Ukraine. Brussels [pdf]. Available at: <http://saee.gov.ua/documents/ Ukraine_EE_2013_ENG.pdf>[Accessed 11 December 2017].

2. Smith, C. B. and Parmenter, K.E., 2016. Energy Management Principles: Applications, Benefits, Savings. $2^{\text {nd }}$ ed. Elsevier.

3. Rossiter, A.P. and Jone, B. P., eds., 2015. Energy Management and Efficiency for the Process Industries. Wiley-AIChE.

4. Thollander, P. and Palm, J., 2013. Improving Energy Efficiency in Industrial Energy Systems. Springer.

5. Kambur, O. and Kostenok, Y., 2015. Features of Stimulating Energy Efficiency in Public and Utility Companies. Investments: Practice and Experiences, 22, pp. 71-74.

6. Bratkovska, O., 2015. About the Energy Model of Sustainable Heat Consumption. Efficient economy, 11, pp. 1-5.

7. Sevastyanov, R., 2016. Energy efficiency of industrial enterprises of Ukraine and barriers for its implementation. Economic bulletin of Zaporozhye state engineering academy, 1, pp. 28-35.

8. Shvetz, V., Palekhova, L., Simon, S., Palekhov, D. and Mammadov, A., 2015. Convergence of Energy Efficiency Policies in the EU and Countries with Economies in Transition. Socio-Economic and Environmental
Problems of the Mining Industry, Building and Energetics. Tula State University, pp. 398-405.

9. Ukrainian Energy Strategy up to 2035: Safety, Energy efficiency, Competitiveness. Order of the Cabinet of Ministers of Ukraine on August 18, 2017 № 605-p.

10. Information Agency Interfax Ukraine, 2017. Increase in energy export by Ukraine in 2017 [online]. Available at: <http://interfax.com.ua/news/economic/416032. html $>$ [Accessed 20 January 2018].

11. State Statistics Service of Ukraine, 2018. Economic statistics-Economic activity-Energy.

12. World Energy Council, 2016. Energy Efficiency Indicators Database [online]. Available at: <https://www. worldenergy.org/data/efficiency-indicators/ $>$ [Accessed 28 November 2017].

13. Palekhov, D. and Kizilova, M., 2016. Methods for Achieving Energy Efficiency Targets: Analysis of Experience in the EU. Bulletin of the Pridneprovsk State Academy of Building and Architecture, 3(216), pp. 34-41.

14. Palekhova, L. and Simon, S., 2016. Competitive Advantages through the Implementation of International Energy Management Standards. Bulletin of the Pridneprovsk State Academy of Building and Architecture, 3(216), pp. 42-51.

15. Umweltbundesamt, 2017. Erneuerbare Energien in Zahlen. Available at: <http://www.umweltbundesamt. de/themen/klima-energie/erneuerbare-energien/ erneuerbare-energien-in-zahlen $>$ [Accessed 15 January 2018].

16. World Energy Trilemma, 2016. Defining Measures to Accelerate the Energy Transition. World Energy Council 2016 with Oliver Wyma, London [pdf]. Available at: <https://www.worldenergy.org/wp-content/uploads/ 2016/05/World-Energy-Trilemma_full-report_2016_ web.pdf $>$ [Accessed 27 September 2017].

17. Schmidt, M., Hansmann, B., Palekhov, D., Pivnyak, G.G., Shemshuchenko, Y., Pavlenko, A., Shapar, A., Shvetz, V. and Palekhova, L., eds., 2016. Management for Sustainable Development in Transitional Economies: Monograph. $2^{\text {nd }}$ ed., revised and expanded. In: Universities in Support of Sustainable Development, Volume 2. State Higher Educational Institution Dnepropetrovsk - Cottbus.

18. Gingrich, S., Kušková, P. and Steinbergera, J.K., 2011. Long-term changes in $\mathrm{CO}_{2}$ emissions in Austria and Czechoslovakia - Identifying the drivers of environmental pressures. Energy Policy, 39(2), pp. 535-543. DOI: $10.1016 /$ j.enpol.2010.10.006.

19. Interconnected Economies: Benefiting from Global Value Chains. Synthesis report, 2013. Organisation for Economic Cooperation and Development, Paris. Available at: <http://www.oecd.org/sti/ind/interconnectedeconomies-GVCs-synthesis.pdf $>$ [Accessed 04 December 2017].

20. Palekhova, L. and Palekhov, D., 2017. Anwendung von Energieeffizienzkriterien für Marktstrategien von Großunternehmen in den Transformationsländern. In: K. Fraňa, S. Simon, J. Grunewald, Herausgeber, 2017. Energieeffizienz im Bauund Maschinenwesen.: Technische Universität in Liberec, pp. 44-53. 


\section{Критерії енергоефективності як основа для розробки ринкових стратегій великих компаній у країнах із перехідною економікою}

В. Я. Швець ${ }^{1}$, Л. Л. Палєхова ${ }^{1}$, Д. Палєхов ${ }^{2}$, С. Сімон $^{2}$

1 - Державний вищий навчальний заклад „Національний гірничий університет“, м. Дніпро, Україна, е-таil: vasil-shvetc@ukr.net; palehovall@gmail.com

2 - Бранденбурзький технологічний університет Коттбус - Зенфтенберг, м. Коттбус, Німеччина, e-mail: dmitry.palekhov@b-tu.de; Sylvio.Simon@b-tu.de

Мета. Виявлення критичної важливості показників енергоефективності для великих промислових компаній із країн з перехідною економікою для підвищення їх конкурентоспроможності на місцевих і світових ринках.

Методика. У роботі представлено історичний огляд загальних енергоефективних принципів i підходів для досягнення сталого розвитку у країнах із різною економічною політикою, включаючи країни з перехідною економікою. Дослідження проводилося шляхом вивчення міжнародних документів, статистичних даних і особливостей національних практик з питань енергоефективності.

Результати. Дослідження розкриває масштаби проблеми енергоефективності у країнах із перехідною економікою та визначає причини відсутності достатнього прогресу в досягненні енергетичної стійкості своїх великих компаній як драйверів підвищення конкурентоспроможності та успішної інтеграції у глобальні виробничо-торговельні ланцюги. У той же час автори проаналізували фактори, що сприяли швидкому успіху деяких країн із соціалістичним минулим у переорієнтації державної політики на принципи енергетичної безпеки та досягнення стійкого економічного зростання. Системний підхід дозволив визначити ряд ключових сил, що пов'язані з енергоефективністю, та їх впливи на досягнення конкурентних переваг. I, нарешті, автори запропонували набір контекстуальних критеріїв для вибору перспективних ринкових стратегій, спрямованих на те, щоб крупні компанії стали частиною комплексних ланцюгів створення вартості, які мають глобальні масштаби.

Наукова новизна. Аналіз довів, що великі компанії у країнах із перехідною економікою для їх інтеграції у сталі ринки повинні враховувати дві групи критеріїв енергоефективності: 1) критерії, що пов'язані зі здатністю компанії поліпшити ситуацію у своїй країні або регіоні; 2) критерії, що пов'язані $з$ вимогами або стандартами, підтримуються або важливі для певного ланцюга створення вартості, в яку входить або має намір увійти компанія.

Практична значимість. Значення нового підходу полягає у тому, що компанія може змінити або розширити стратегію 'проштовхування' для позиціонування свого бізнесу на зовнішньому ринку, що в даний час є звичайною практикою для українських підприємств. Запропонована система кри- теріїв може стати основою для розробки стратегії 'втягування', що буде орієнтована на цілі сталого розвитку всіх трьох груп зацікавлених сторін: самої компанії, регіону або країни, а також ділових партнерів - ланцюга створення вартості.

Ключові слова: енергоефективність, глобальні виробничо-збутові ланцюги, ринкові стратегії, сталий розвиток, економіка перехідного періоду

\section{Критерии энергоэффективности как основа для разработки рыночных стратегий крупных компаний в странах с переходной экономикой}

\section{В. Я. Швец ${ }^{1}$, Л. Л. Палехова ${ }^{1}$, Д. Палехов ${ }^{2}$, С. Симон ${ }^{2}$}

1 - Государственное высшее учебное заведение „Национальный горный университет“, г. Днепр, Украина, e-mail: vasil-shvetc@ukr.net; palehovall@gmail.com

2 - Бранденбургский технический университет Коттбус - Зенфтенберг, г. Коттбус, Германия, e-mail: dmitry. palekhov@b-tu.de; Sylvio.Simon@b-tu.de

Цель. Выявление критической важности показателей энергоэффективности для крупных промышленных компаний из стран с переходной экономикой для повышения их конкурентоспособности на местных и мировых рынках.

Методика. В этой работе представлен исторический обзор общих принципов и подходов к энергоэффективности в контексте перехода к устойчивому развитию в странах с разной экономической политикой, включая страны с переходной экономикой. Исследование основывалось на анализе международных документов и отчетов, статистических данных и национальных практик, касающихся энергоэффективности и энергосбережения.

Результаты. Исследование раскрывает масштабы проблемы энергоэффективности в странах с переходной экономикой и определяет причины отсутствия достаточного прогресса в достижении энергетической устойчивости их крупных компаний как драйверов повышения конкурентоспособности и успешной интеграции в глобальные производственно-сбытовые цепочки. В то же время авторы проанализировали факторы, которые способствовали стремительному успеху некоторых стран с социалистическим прошлым в переориентации государственной политики на принципы энергетической безопасности и достижения устойчивого экономического роста. Системный подход позволил выявить ряд ключевых сил, связанных с энергоэффективностью, и их воздействие на достижение конкурентных преимуществ. И, наконец, авторы предложили набор контекстуальных критериев для выбора перспективных рыночных стратегий, направленных на то, чтобы крупные компании стали частью комплексных цепочек создания стоимости, имеющих глобальные масштабы.

Научная новизна. Анализ доказал, что в странах с переходной экономикой для интеграции в устойчивые рынки крупные компании должны учиты- 
вать две группы критериев энергоэффективности: 1) критерии, которые связаны со способностью компании улучшить ситуацию в своей стране или регионе; 2) критерии, которые связаны с требованиями или стандартами, поддерживаются или важны для определенной цепочки создания стоимости, в которую входит или намеревается войти компания.

Практическая значимость. Значение нового подхода состоит в том, что компания может изменить или расширить стратегию 'проталкивания' для позиционирования своего бизнеса на внешнем рынке, которая в настоящее время является обычной практикой для украинских предприятий. Предла- гаемая система критериев может стать основой для разработки стратегии 'втягивания', которая будет ориентирована на цели устойчивого развития всех трех групп заинтересованных сторон: самой компании, региона или страны, а также деловых партнеров - цепочки создания стоимости.

Ключевые слова: энергоэффективность, глобальные производственно-сбытовые цепочки, рыночные стратегии, устойчивое развитие, экономика переходного периода

Рекомендовано до публікації докт. техн. наук П.І.Пономаренком. Дата надходження рукопису 17.12.17. 